\title{
The Pragmatic Significance of Statements on the Back of Vehicles
}

\author{
Ala'a Abdulkareem Sa'adeh \\ Department of Arts, Zarqa University, PO box 2000 - Zarqa 13110 Jordan
}

\section{The research is financed by the Deanship of Research in Zarqa University /Jordan}

\begin{abstract}
In everyday conversations we often convey information that goes above and beyond what we strictly speaking say. One of these every day conversations is written or spoken, the most practical example of everyday written conversation is; what is written on the back of some vehicles. So the study aims at finding answers of how such things are produced and understood in conversation and how a person gets from what is said to what is meant, or from the expressed meaning to the implied meaning.

The goal of this study is achieved by choosing randomly statements that are written on the back of some vehicles which have implicature, then analyzed their conversational implicature.

The researcher found out how much these statements have conversational implicature and if it is frequent in these statements.
\end{abstract}

Key words: Implicature, pragmatics, cars.

DOI: $10.7176 /$ RHSS/9-11-11

Publication date:June $30^{\text {th }} 2019$

\section{Introduction}

Pragmatics is a branch of linguistics dealing with language in use and the contexts in which it is used, including such matters as deixis, the taking of turns in conversation, text organization, presupposition, and implicature. Although most of people don't know what is the implicature, but they use it in everyday conversations to convey their thoughts, ideas.... etc.

Mey (1993:6) defined pragmatics as "the study of the use of langaue in human communication as determinded by the conditions of society" . Grice (1989) defined implicature as "implying but not uttering intended meanings, when what is meant is not what is said. He proposed a rationalist philosophical model of how such things are produced and understood in conversation". This study came to concentatre on the implicature and what pragmatic functions it can reveal and how it violates the Grice's priciple of relevance.

Also, the study sheds the light on collecting diffenent examples of implicature, such as conversational implicature from the statements that are written on the back of some vehicles.

\section{Literature Review}

The topic of implicature has been discussed by many authors, who start their study by giving some explanations for the term itself, its types and some examples from literary works.

Grice (1989) defined implicature as "implying but not uttering intended meanings, when what is meant is not what is said. He proposed a rationalist philosophical model of how such things are produced and understood in conversation".

Yule, G (1996) states that implicature "is the study of contextual meaning. Implicature is the study how more gets communicated than is said. Implicature is the study of expression of relative closeness. Implicature is the study of speaker's meaning".

R.HORN,LAURENCE (2006) defined Implicature as " a component of speaker meaning that constitutes an aspect of what is meant in a speaker's utterance without being part of what is said". Conversational implicature is a meaning or message that is implicated in a conversation. When people over say (or say more of ) or under say (say less of ) something, they produce certain extra meaning or meanings beyond the literal meanings of words and sentences. This extra meaning is conversationally dependent, hence conversational implicature.

Thomas (1995) From among those influential theories is Grice's theory of Conversational Implicature where in Grice attempts to show systematically how a person gets from what is said to what is meant, or from the expressed meaning to the implied meaning.

Ward (2005) introduces the implicature as the distinction between "the said and the meant the implicated and the unsaid". Furthermore, they go on to say that implicature means the additional meaning or saying little and meaning more.

Levinson (1983) states that the notion of implicature provides some explicit account of how it is possible to mean more than what is literally expressed in the conventional sense of the linguistic expression uttered.

Pratt (1977) argues that implicature has been used a great deal by writers of literature and also by politicians, press agents, advertisers and other speakers interested in multiple meanings.

Grice (1975) makes two distinctions between what is said by speaker of a verbal utterance and what is 
implied. What is implied might be either conventional (largely generated by the standing meaning) or conversational (dependent on the assumption that is speaker obeying the rules of conversation to the best of their ability).

Implicature as Levinson (1995) defined, is "the aspect of meaning that a speaker conveys, implies, or suggests without directly expressing".

Gazdar (1979) defines Implicature is anything that is inferred from an utterance but that is not a condition for the truth of utterance.

Grundy (2000) states the contribution of notion of implicature is that it provide some explicit account of how it is possible to mean (in some general sense) more than what is actually ,said ( more than what is literally expressed by the conventional sense of linguistic expression uttered).

\section{Research Problem}

The deep meaning $\&$ thinking are requested when encountering such implicatures other than the surface meaning $\&$ thinking.

\subsection{Research Question}

This study aims at answering the following questions:

- What is the conversational implicature in the statements that are written on the back of some vehicles?

- $\quad$ Is it frequent in the statements that are written on the back of some vehicles?

\subsection{Objectives of the Study}

This study combined both qualitative and quantitative data in an effort to obtain accurate outcomes and sufficient information, and the results were then reported.

The researcher randomly chooses 21 examples of implicature from the statements that are written on the back of some vehicles, she translated them from Arabic to English then analyzed their conversational implicature.

\section{Discussion \& Analysis}

$$
\text { * متى هدف حياتي طلع تسلل }
$$

Social experience or feeling.

In this metaphorical expression, the driver means that his goal in life is fake like the offside goal in football match.

No result in both conditions. The implicature norm is that all his hopes and expectations failed.

$$
\text { * كلام الناس مكالمة لم يرد عليها }
$$

In this metaphorical expression, he indicates that he didn't pay attention to the people's talk, and he considers the people's talk as a missed call.

He ignores the people's talk like he ignores the mobile's call.

$$
\text { * رميت همومي في البحر طلع السمك يلطم }
$$

The driver implicates that; because he has many troubles, he imagined that if he threw these troubles in the sea, the fish will come to the surface and weep.

$$
\text { * زينها مع الله تزين }
$$

Religious attention.

Fill your life with words of Islam that close yourself from Allah, then you will feel happy and satisfied.

$\mathbf{A}$ is right then $\mathbf{B}$ will be right.

$$
\text { * هل صليت على النبي اليوم (صلى الله عليه وسلم) }
$$

Religious attention (a call for Allah).

A kind of preaching and calling to pray upon prophet Mohammad to earn Hasanat from Allah.

$$
\text { * ملعة من دبي محنا طالعين }
$$

A kind of rebel saying and rejection for a political situation, a group decision of saying we won't go out.

The presupposition is the fact of staying in homeland.

$$
\text { * اليمامة }
$$

One word اليمامة does he mean?

Is it a nickname for his bus because some people give their cars names, or the driver is fast like the dove?

A kind of ambiguity implied in this utterance.

The background is; dove flies fast.

$$
\text { * فكرك بتهون }
$$

A question?

This person is facing a lot of troubles in his life, his soul; confused mind and feeling unconfident if that will end, so he asked this question. 
The answer will be yes " ان مع العسر يسر " البحر والح ", because we have a merciful Allah who creates us.

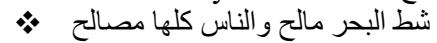

The implied meaning; no one does any favor for free.

The metaphorical expression salty sea beach, like people who serve for something like salt.

The people don't remember him, but only when they want something from him.

$$
\text { * ما أحلى الحياة في طاعة الله }
$$

The implied meaning; a happy religious experience.

What a sweat life with Allah! Obeying him is a call for you to do it.

$$
\text { * أمامك معرض جديد }
$$

An advertisement.

He described his individual car as a whole cars exhibition, as assign to pay attention to the driver by looking at his car (proud of himself or his car?).

$$
\text { * استنوني لما أكبر }
$$

This utterance written on a small car, because his car is small, he said wait for it until it grows up as if it is a living being that will grow up by time.

$$
\text { • معب نلقى الوفي في هالزمن }
$$

A personal experience.

He generalized it in this sentence to imply that loyalty is an exceptional attitude.

(the hidden pronoun which refers to us generalizes the fact of a human manner).

$$
\text { * الله يهدينا دامه يمدينا }
$$

لا تفوتلك الجنة

A religious call.

God always leads us to faith as far as we are living, the utterance is an advice to inter paradise.

$$
\text { * راجعة باذن الله }
$$

This utterance is written on the back of a big lorry that carry damaged cars.

So he assumed that damaged car is saying I will come back (In sha Allah) a religious utterance means Allah's willing.

The metaphoric picture is expressed by presenting the car as a human female.

$$
\text { * احتر ام الكبير واجب }
$$

An ethic attitude respect elder people.

This utterance is written on the back of a big car, because it is bigger than other cars, so others should respect it. Locution match with hidden meaning.

$$
\text { * عذاب الكباو لا عشق البنيا }
$$

It is a taboo utterance about special social community, these kind of words show the idea of suffering in love.

Showing the fact of suffering is compared by the KIA car that wrecked a lot, and loving of his girl.

* ن ناس مرضى، يجعلها ما ترضى

Because those people who have psycho disease, their punishment is dissatisfaction in their life.

This is a kind of revenge that some people hurt the addresser, because they are psycho from this point of view.

Given theme; good ethics for healthy society.

$$
\text { * وقفنت هيبة.. كيف لو مشيت؟ }
$$

Indicates that the car has a high position, in its standing and walking.

$$
\text { * اللهم أعطهم ضعف ما يتمنون لي }
$$

Does the addresser wish him positive attitudes or negative attitudes? he asks Allah to give them their intuition.

Given theme; two kinds of people's classification, good and bad intuition.

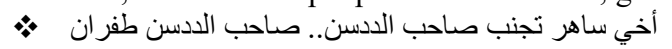

He asked the radar to stay away from him, because he is poor, and he addressed the radar as a human being. Given theme; people suffer from poverty.

\section{Results}

This study reveals how much implicature is used in the statements that are written on the back of some vehicles and how each statement has a conversational implicature that has an implied meaning, and how such things are produced and understood in conversation. The deep meaning \& thinking are requested when encountering such implicatures and it was clear-cut how they violated the Grice's maxim of relevance in which the speaker means the deep meaning of his / her words other than the surface meaning.

\section{Limitation of the Study}

Paul Grice identified three types of general conversational implicatures:

1. The speaker deliberately flouts a conversational maxim to convey an additional meaning not expressed literally. For instance, a speaker responds to the question "How did you like the guest lecturer?" with the 
following utterance:

Well, I'm sure he was speaking English.

If the speaker is assumed to be following the cooperative principle, in spite of flouting the Maxim of Relevance, then the utterance must have an additional nonliteral meaning, such as: "The content of the lecturer's speech was confusing."

2. The speaker's desire to fulfill two conflicting maxims results in his or her flouting one maxim to invoke the other. For instance, a speaker responds to the question "Where is John?" with the following utterance:

\section{He's either in the cafeteria or in his office.}

In this case, the Maxim of Quantity and the Maxim of Quality are in conflict. A cooperative speaker does not want to be ambiguous but also does not want to give false information by giving a specific answer in spite of his uncertainty. By flouting the Maxim of Quantity, the speaker invokes the Maxim of Quality, leading to the implicature that the speaker does not have the evidence to give a specific location where he believes John is.

3. The speaker invokes a maxim as a basis for interpreting the utterance. In the following exchange:

Do you know where I can get some gas?

There's a gas station around the corner.

The second speaker invokes the Maxim of Relevance, resulting in the implicature that "the gas station is open and one can probably get gas there".

\section{Conclusion}

It can be concluded how much important to understand the implicature, and how does meaning imply in an utterance, to understand the addresser and communicate with him her without any troubles, to know how we should deal with such statements which contain implicature and to not have any troubles in our everyday conversations.

The researcher found out that utterances at the back of some vehicles are not for fun, but they convey messages deeply. Such as:

- Wisdom.

- Political attention.

- Religious attitudes.

- Social positive and negative habits.

- Personal ethical experience.

\section{References}

Gazdar, Gerald (1979) Pragmatics, Implicature, Presupposition and Logical Form. Florida Academis Press. INC Grice, H. Paul. (1989). Studies in the Way of Words. Cambridge, Mass.: Harvard University Press.

Grice, H.Paul (1975) Logic and Conversation. New York: Oxford University Press.

Grundy, P. (2000). Doing Pragmatics. London: Arnold.

Levinson, S. 1983 Pragmatic, Cambridge: Cambridge Univ. Press.

Levinson, S. C. (1995). Pragmatics. Cambridge: Cambridge University Press.

Pratt, M. 1977; Toward a Speech Act Theory of Literary Discourse, London: Indian Univ. Press.

R.HORN,LAURENCE(2006), A HANDBOOK OF PRAGMATICS

Thomas, J. (1995). Meaning in Interaction: an Introduction to Pragmatics. Longman, London and New.

Ward, L. R. (2005). The Handbook of Pragmatics. Blackwell: Blackwell Publishing.

Yule, G (1996) PRAGMATICS 